\title{
Rolul determinării volumului trombocitar mediu și a raportului trombocite/limfocite în evaluarea severității infecțiilor respiratorii acute la copii
}

\author{
Diana Mădălina Chiheri ${ }^{1}$, Maria Oana Săsăran², Lorena Elena Meliț ${ }^{3}$ \\ ${ }^{1}$ Universitatea de Medicină, Farmacie, Științe și Tehnologie „George Emil Palade“, Tg. Mureș, România \\ ${ }^{2}$ Pediatrie III, Universitatea de Medicină, Farmacie, Științe și Tehnologie \\ "George Emil Palade", Tg. Mureș, România \\ ${ }^{3}$ Pediatrie I, Universitatea de Medicină, Farmacie, Științe și Tehnologie \\ "George Emil Palade", Tg. Mureș, România
}

\begin{abstract}
REZUMAT
Introducere. Infecțiile respiratorii acute fac parte din categoria afecțiunilor cu o frecvență ridicată în rândul pacienților pediatrici. Deși majoritatea evoluează favorabil, insuficiența respiratorie acută este una dintre complicațiile majore posibile ale acestora, fiind principala cauză responsabilă de mortalitatea crescută. Diferiți parametri ușor accesibili, obținuți ca urmare a efectuării unei simple hemoleucograme, pot fi considerați biomarkeri inflamatori, utili în diagnosticul și prognosticul multiplelor afecțiuni, inclusiv al infecțiilor respiratorii acute. Printre aceștia se numără volumul mediu trombocitar și raportul trombocite/limfocite.

Obiective. Prin acest studiu, ne propunem să investigăm utilitatea volumului trombocitar mediu şi a raportului trombocite/limfocite în distingerea infecțiilor respiratorii necomplicate de cele cu potential evolutive spre insuficiență respiratorie acută.

Material și metode. Am efectuat un studiu prospectiv pe 62 de pacienți cu vârste cuprinse între 1 lună și 10 ani, cu diverse afecțiuni respiratorii, diagnosticate pe baza tabloului clinic, paraclinic și a radiografiei toracice. $O$ hemoleucogramă automată a fost efectuată la fiecare pacient.

Rezultate. Lotul de studiu a cuprins 26 pacienți cu infecții respiratorii complicate cu insuficiență respiratorie acută, în lotul martor fiind încadrați restul pacienților, cu infecții respiratorii acute necomplicate $(N=36)$. Sexul și mediul de proveniență nu au diferit semnificativ între cele două loturi. Volumul mediu trombocitar a fost semnificativ scăzut în lotul de studiu ( $p=0,0104)$, fiind asociat cu infectiile respiratorii severe. Rezultate similare, semnificative statistic, au fost obținute și prin compararea acestui parametru în subloturile de cazuri cu pneumonie, respectiv bronșiolită acută. Valori crescute ale raportului trombocite/limfocite au fost, de asemenea, corelate cu infecțiile respiratorii complicate cu insuficiență respiratorie $(p=0,0445)$.

Concluzii: Rezultatele acestui studiu indică utilitatea folosirii volumului mediu trombocitar și a raportului trombocite/ limfocite ca markeri predictivi în dezvoltarea insuficienței respiratorii acute la copiii cu patologii respiratorii. Totuși, studii prospective observaționale, pe grupuri mai mari de pacienți, sunt necesare pentru a obține rezultate adecvate, relevante la o scară populațională mai largă.
\end{abstract}

Cuvinte cheie: volum trombocitar mediu, raport trombocite/limfocite, insuficiență respiratorie acută, copii, inflamație

\section{INTRODUCERE}

Conform Organizației Mondiale a Sănătății, infecțiile respiratorii reprezintă $6 \%$ dintre motivele cauzatoare de boală în lume, iar în fiecare an peste 12 milioane de copii cu vârsta sub 5 ani sunt internaţi cu patologie respiratorie infecțioasă, dintre care aproxi- mativ 6,6 milioane decedează (1). Insuficiența respiratorie acută este una dintre complicațiile majore, direct responsabilă de mortalitatea ridicată a infectiilor respiratorii la copil, în lipsa accesului rapid la terapia specifică. Oxigenoterapia este tratamentul de primă intenție, atunci când valorile saturației de oxigen sunt mai mici sau egale cu 92 sau când presiunea parțială a 
oxigenului în sânge este mai mică de 60 mmHg $(2,3)$. Prin urmare, o recunoaștere precoce a cazurilor cu evoluție potențial severă este necesară pentru stratificarea riscului, diverși parametri ușor accesibili, obținuți ca urmare a unei simple hemoleucograme automate, fiind utili în această privință (4).

În orice proces infecțios care are loc la nivelul căilor respiratorii, agenții patogeni au capacitatea de a activa o multitudine de citokine inflamatorii care mediază răspunsul imun. Dintre acestea, un rol deosebit îl joacă tumor necrosis factor- $\alpha$ (TNF- $\alpha)$ şi interleukina-6 (IL-6), care, prin stimulare secreției de trombopoietină, facilitează eliberarea de trombocite în circulație. Se explică astfel apariția trombocitozei reactive în asociere directă cu severitatea infecției și, implicit, a răspunsului inflamator (5). Numărul de limfocite are, de asemenea, un important rol predictiv, fiind scăzut în context de sepsis sau bacteriemie, ca urmare a apoptozei limfocitelor T, respectiv B (6). Limfopenia s-a dovedit a fi, de asemenea, un marker predictiv al mortalitățiii $(6,7)$. Având în vedere variația individuală a acestor parametri, se explică popularizarea raportului trombocite/limfocite ca biomarker infecțios sau inflamator, creșterea acestuia fiind corelată cu diverse tipuri de procese infecțioase, inclusiv infecții respiratorii, infecții de tract urinar, infecția cu Helicobacter pylori sau malaria (4). Dintre infecțiile respiratorii, cel mai intens studiate au fost diferitele tipuri de pneumonii și, mai recent, infecția cu noul virus SARS-Cov2, dovedindu-se o relație strânsă între raportul trombocite/limfocite și severitatea sau prognosticul acestora $(8,9)$.

Volumul trombocitar mediu (VTM), identificat de rutină cu ajutorul hemoleucogramei automate, reprezintă mărimea trombocitelor circulante, fiind corelat cu funcția sau activarea plachetară (10). VTM este influențat de procesul de trombopoieză, mărimea trombocitelor circulante fiind expresia diverselor stadii de maturație ale acestora. Prin urmare, trombopoieza accelerată, ce apare în context inflamator, se poate asocia cu creșterea valorii medii a volumului plachetar, VTM fiind intens studiat în relație cu boala inflamatorie intestinală, spondilita anchilozantă sau artrita reumatoidă (11-13). Cu toate acestea, există studii care au dovedit o tendință descendentă a valorilor VTM în diverse patologii, un exemplu fiind bronşiolita acută la sugar sau la copilul mic (14).

Prin acest studiu, ne propunem să stabilim rolul VTM și al raportului trombocite/limfocite în evaluarea severității infecțiilor respiratorii acute la copii. Întrucât datele pe această temă sunt limitate, numărul de studii efectuate pe populația pediatrică fiind redus, ne dorim să stabilim în ce măsură acești parametri ar putea fi folosiţi în viitor pentru a diferenția patologiile respiratorii comune de cele cu potențial evolutiv spre insuficiență respiratorie acută.

\section{MATERIAL ȘI METODĂ}

Am efectuat un studiu prospectiv pe 62 de pacienți cu infecții respiratorii acute, cu vârste cuprinse între 1 lună şi 10 ani (numărul pacienților spitalizați cu aceste tipuri de patologii peste vârsta de 10 ani a fost redus, fiind limitat la câteva cazuri individuale), care au fost spitalizați în Clinica Pediatrie I a Spitalului Clinic Județean de Urgență Tg. Mureș, în perioada martie 2019 - martie 2020. Studiul a inclus pacienți cu simptome respiratorii comune, cum ar fi obstrucția nazală, rinoreea, tusea, disfagia, spitalizați pentru simptome generale marcate (febră, inapetență, grețuri, vărsături, sindrom de deshidratare acută) sau fenomene de detresă respiratorie acută. La fiecare pacient s-a recoltat cel puțin o probă de sânge venos în vederea efectuării hemoleucogramei automate, de unde au fost consemnate volumul mediu trombocitar, numărul absolut de limfocite şi trombocite. Au fost excluşi din studiu pacienții cu afecțiuni cronice cunoscute, inclusiv cei cu boli respiratorii cronice ce predispun la infecții respiratorii complicate sau cu evoluție potențial severă, cum ar fi fibroza chistică, astmul bronşic sau bronhodisplazia pulmonară. Împărțirea pacienților în cele două loturi, a pacienților cu infecții respiratorii necomplicate și a celor cu infecții respiratorii complicate cu insuificență respiratorie acută, s-a făcut în funcție de valorile saturației în oxigen $(\mathrm{SaO} 2)$ în aerul ambiental la momentul internării, subiecții cu valori ale $\mathrm{SaO} 2 \leq 92 \%$ fiind încadrați în cea de-a doua categorie.

Prelucrarea statistică a datelor a fost realizată cu ajutorul softului GraphPad PrismT. Testul MannWhitney a fost utilizat pentru compararea mediilor între cele două grupuri, întrucât variabilele studiate nu respectau o distribuție gaussiană. Pentru valoarea $\mathrm{p}$, pragul de semnificație statistică a fost stabilit la 0,05 (corespunzător unui interval de confidență de 95\%).

Studiul a fost aprobat de comisia de etică a Spitalului Clinic Județean de Urgență Tg. Mureș. Au fost incluși în studiu doar pacienții ai căror tutori legali au semnat consimţământul informat, dându-și astfel acordul pentru includerea în studiu.

\section{REZULTATE}

Din lotul total de cazuri ( $\mathrm{N}=62)$, în lotul studiu au fost încadrați pacienții cu infecții respiratorii complicate cu insuficiență respiratorie acută $(N=26)$, iar lotul martor a cuprins pacienți cu infecții respiratorii acute necomplicate $(\mathrm{N}=36)$. Diagnosticul afecțiunilor 
respiratorii a fost stabilit în funcție de tabloul clinic, paraclinic și aspectul radiologic (acolo unde radiografia toracică a fost necesară). Distribuția populației incluse în studiu în funcție de diagnosticul stabilit este ilustrată în figura 1. Se remarcă o predominanță absolută a cazurilor de pneumonie, ce au reprezentat peste jumătate din întreaga populație cuprinsă în studiu (52\%), urmate de cazurile de bronșiolită acută (17\%).
Vârsta medie a pacienților incluși în studiu a fost de 2,44 ani $\pm 2,13$ DS, distribuția pe grupe de vârstă putând fi vizualizată în figura 2 . Nu a existat o diferență semnificativ statistică între cele două loturi în ceea ce privește vârsta $(p=0,3923)$. În ceea ce privește distribuția pe sexe, majoritatea pacienților incluși în studiu au fost de sex masculin, cu o pondere de $65 \%$, corespunzătoare unui raport pe sexe de 1,88:1 (fig. 3).

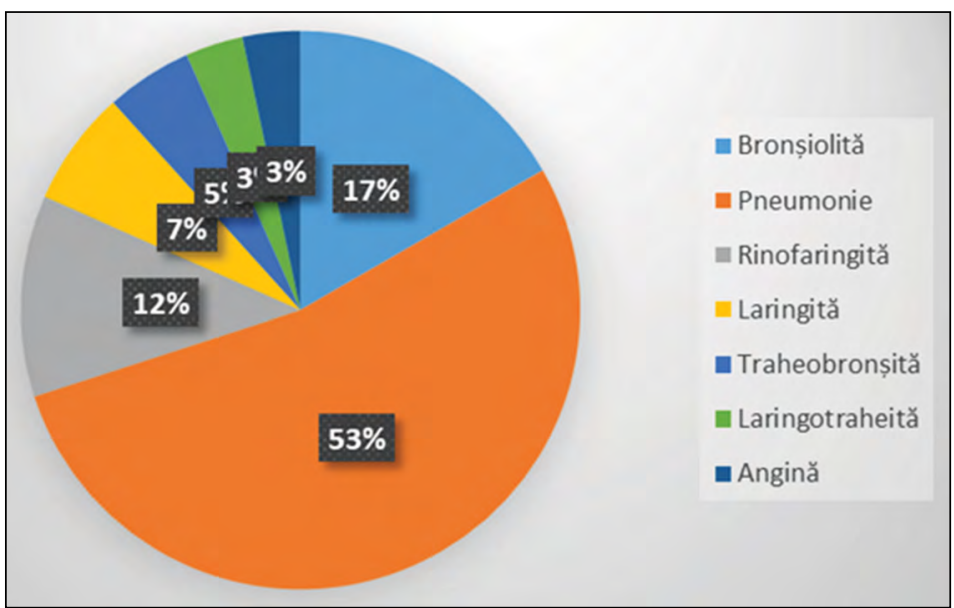

FIGURA 1. Distribuția diagnosticelor aparținând lotului întreg de cazuri

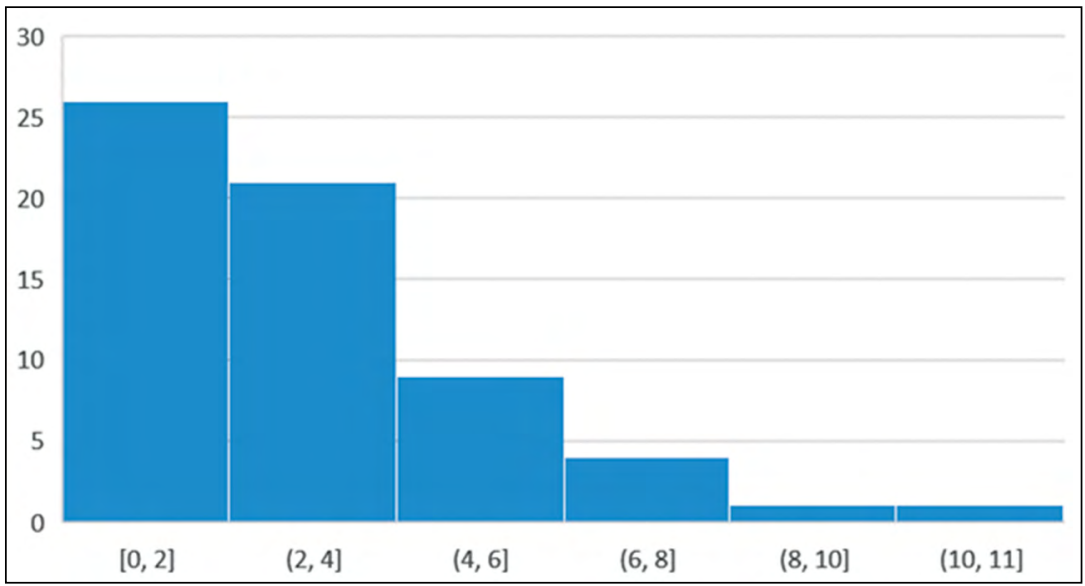

FIGURA 2. Distribuția pe categorii de vârstă

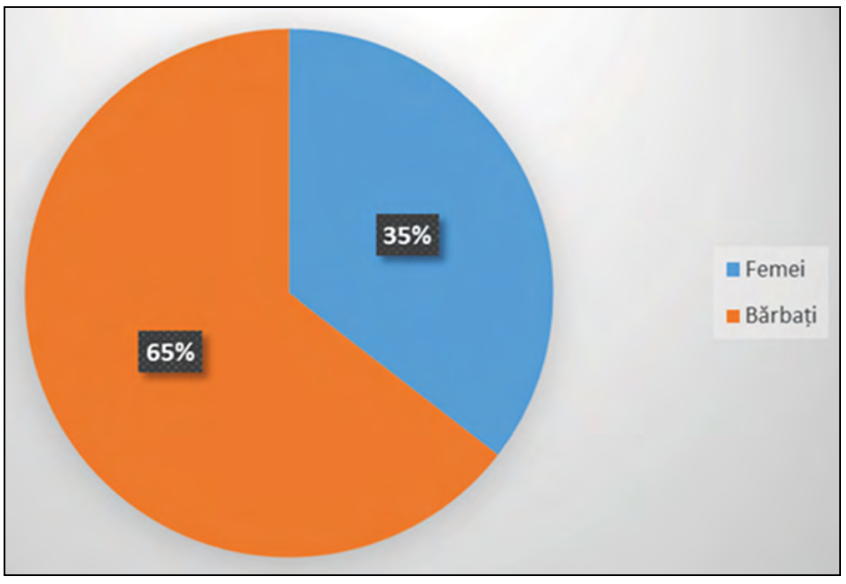

FIGURA 3. Distribuția pe sexe a lotului de studiu 
Sexul masculin sau feminin nu influențează riscul de dezvoltare a insuficienței respiratorii acute, distribuția pe sexe nefiind semnificativ diferită între cele două loturi (fig. 4, p =0,999, RR =0,958, CI 95\%).

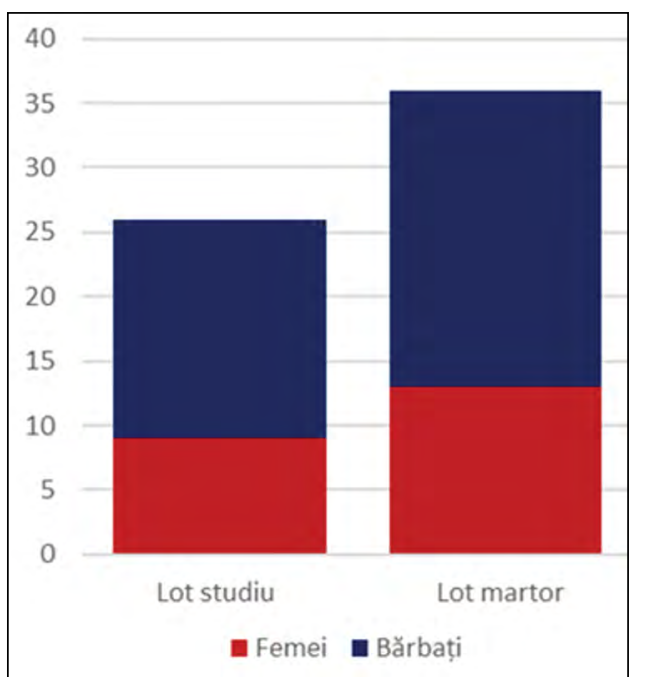

FIGURA 4. Distribuția pe sexe în funcție de severitatea infecțiilor respiratorii acute

Un procentaj identic distribuției pe sexe, de $65 \%$, respectiv $35 \%$, s-a remarcat la cele două medii de proveniență (rural, respectiv urban) în lotul de studiu, precum se poate vedea în figura 5 .

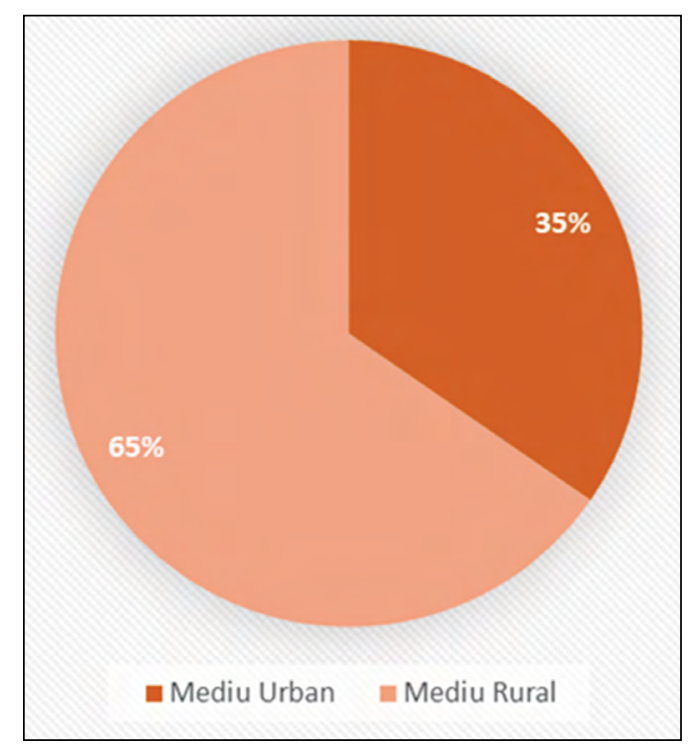

FIGURA 5. Mediu de proveniență

$\mathrm{Cu}$ toate acestea, proveniența din mediu rural sau urban nu este net diferită între cele două loturi și nu influențează dezvoltarea insuficienței respiratorii acute $(\mathrm{p}=0,301, \mathrm{RR}=0,692$, CI 95\%).

Tabelul 1 reflectă comparația celor două loturi din punctul de vedere al valorilor medii ale VTM, respectiv al raportului trombocite/limfocite. Valoarea medie a VTM a fost semnificativ mai mică în lotul de studiu
$(8,972 \pm 1,868$ DS $)$ ca în lotul martor $(9,345 \pm 1,160$ DS, $p=0,0104)$. Pe de altă parte, raportul trombocite/ limfocite a prezentat valori medii semnificativ mai crescute la pacienții cu insuficiență respiratorie acută față de cei cu infecții respiratorii necomplicate $(160,9 \pm 101,1$ DS, față de $113,4 \pm 71,50$ DS, p = $0,0445)$.

TABEL 1. Comparația parametrilor între grupul cu insuficiență respiratorie acută și lotul martor

\begin{tabular}{|c|c|c|c|}
\hline Parametru & $\begin{array}{c}\text { Lot studiu } \\
\text { mean } \pm \text { SD } \\
\text { (median) }\end{array}$ & $\begin{array}{c}\text { Lot martor } \\
\text { mean } \pm \text { SD } \\
\text { (median) }\end{array}$ & $\begin{array}{c}\text { Valoarea } \\
\text { lui } p\end{array}$ \\
\hline VTM & $\begin{array}{c}8,972 \pm 1,868 \\
(8,600)\end{array}$ & $\begin{array}{c}9,345 \pm 1,160 \\
(9,400)\end{array}$ & $p=0,0104$ \\
\hline Raport & $160,9 \pm 101,1$ & $113,4 \pm 71,50$ & $p=0,0445$ \\
Trombocite/ & $(137,8)$ & $(86,27)$ & \\
Limfocite & & & \\
\hline
\end{tabular}

Având în vedere că numărul pacienților cu alte patologii în afară de pneumonie, respectiv bronșiolită acută, cu prevalență crescută în rândul subiecților incluși în studiu, a fost redus, am considerat inoportună analizarea celor doi parametri pentru cazuri individuale ale altor tipuri de afecțiuni. Rezultate similare celor obținute la analiza celor două loturi au fost obținute pentru valorile VTM, pentru subloturile de bronșiolită și pneumonie (tabelul 2), acestea fiind considerabil mai scăzute la pacienții cu insuficiență respiratorie acută $(\mathrm{p}=0,0159$, respectiv $\mathrm{p}=0,0224)$.

TABEL 2. Comparația valorilor VTM pentru pacienții diagnosticați cu pneumonie sau bronșiolită

\begin{tabular}{|c|c|c|c|}
\hline VTM & Lot studiu & Lot martor & $p$ \\
\hline Pneumonie & $\begin{array}{c}8,427 \pm 1,265 \\
(8,600)\end{array}$ & $\begin{array}{c}9,151 \pm 1,358 \\
(9,300)\end{array}$ & $p=0,0224$ \\
& $\begin{array}{c}8,660 \pm 0,6025 \\
(8,500)\end{array}$ & $\begin{array}{c}10,22 \pm 0,8729 \\
(10,20)\end{array}$ & $p=0,0159$ \\
\hline Bronșiolită & & \\
\hline
\end{tabular}

Raportul trombocite/limfocite, pentru pacienții diagnosticaţi cu pneumonie, nu a prezentat valori semnificativ diferite la subiecții cu insuficiență respiratorie acută $(p=0,266)$. Pentru sublotul de pacienţi diagnosticați cu bronșiolită, rezultatele au variat în sens crescător, lotul de studiu prezentând valori mai mari ca lotul martor, dar fără corelații semnificative statistic (tabelul 3).

TABEL 3. Comparația valorilor raportului trombocite/ limfocite pentru pacienții diagnostigați cu pneumonie sau bronșiolită

\begin{tabular}{|c|c|c|c|}
\hline $\begin{array}{c}\text { Raport } \\
\text { trombocite/ } \\
\text { limfocite }\end{array}$ & Lot studiu & Lot martor & $p$ \\
\hline Pneumonie & $\begin{array}{c}156,5 \pm 88,54 \\
(140,4)\end{array}$ & $\begin{array}{c}119,9 \pm 68,94 \\
(105,3)\end{array}$ & $p=0,2666$ \\
\hline Bronșiolită & $122,4 \pm 77,61$ & $56,70 \pm 15,16$ & $p=0,3095$ \\
& $(106,9)$ & $(57,50)$ & \\
\hline
\end{tabular}




\section{DISCUȚII}

Parametrii hematologici ca VTM sau raportul trombocite/limfocite, alături de raportul neutrofile/ limfocite, monocite/limfocite sau de indicii eritrocitari, au devenit tot mai intens studiaţi în relație cu diagnosticul sau prognosticul diverselor patologii. Deși majoritatea studiilor disponibile în literatură au fost efectuate pe pacienți aflați la vârsta adultă, raportul trombocite/limfocite sau VTM s-au dovedit utili ca biomarkeri inflamatori în diverse afecțiuni specifice vârstei pediatrice, cum ar fi reumatismul articular acut (15), rujeola (16), apendicita acută (17), purpura Henoch-Schönlein (18) sau diabetul zaharat tip 1 (19). $\mathrm{Cu}$ toate acestea, utilitatea acestor parametri este pusă sub semnul întrebării de multipli autori, care contestă relevanța acestora din cauza lipsei standardizării intervalelor de referință la persoanele sănătoase. Un studiu efectuat pe o populaţie numeroasă, în Coreea de Sud, a încercat să stabilească valori de referință pentru parametrii menționați anterior, în funcție de vârstă și sex, însă a inclus preponderent pacienți de vârstă adultă și a realizat un grup de vârstă unic, sub 19 ani, pentru populația pediatrică. Autorii au subliniat necesitatea dezvoltării unor astfel de studii pe populații din diverse regiuni ale lumii, întrucât valorile propuse de ei pot varia în funcție de rasă și areal geografic (20). Un alt studiu, efectuat pe o populaţie sănătoasă, de sex masculin, din Iran, a dovedit că intervalele de referință ale VTM variază semnificativ în funcție de vârstă (21). Prin urmare, în lipsa unor valori de referință pe populația sănătoasă, diferențele valorilor medii ale diverşilor parametri hematologici între copiii sănătoși și cei cu diverse patologii sunt dificil de analizat. Prin prezentul studiu, am dorit să investigăm prospectiv semnificația clinică a VTM și a raportului trombocite/limfocite din punctul de vedere al predictibilității agravării infecțiilor respiratorii acute la copil. Lipsa includerii unui lot de pacienți sănătoși, ca lot de referință, poate fi motivată prin dificultatea obținerii datelor de la subiecți fără patologii în mediul spitalicesc și prin problematica intervalelor de referință, expusă anterior.

VTM a fost investigat în relație cu multiple afecțiuni respiratorii, una dintre cel mai intens studiate fiind tuberculoza. Esra Ertan Yazar și colab. au obținut în cadrul unui studiu valori semnificativ mai mici ale VTM la pacienții cu tuberculoză pulmonară activă față de persoanele sănătoase, dar au concluzionat că acest parametru nu este un marker semnificativ în evaluarea severității unei astfel de infecții (22). Valorile VTM au fost, de asemenea, studiate în relație cu bronşiolita. Un studiu efectuat în Turcia realizat pe
284 de pacienți a raportat valori mai mari ale VTM la grupul de pacienți cu bronșiolită decât la cei sănătoși. Autorii au explicat acest rezultat prin stimularea trombopoiezei în context inflamator, ce duce la eliberarea de precursori trombocitari imaturi, cu volum celular mare în circulație (23). Rezultatele obținute în studiul nostru sunt contrare concluziilor studiului menționat anterior, întrucât formele severe de bronșiolită, asociate cu insuficiență respiratorie acută, par să influențeze valorile VTM în sens descendent. Pe de altă parte, există și studii care susțin ipoteza noastră, dovedind o asociere între bronșiolită, infecția cu virusul sincițial respirator și scăderea valorilor VTM $(14,24)$.

Karadag-Oncel și colab. au demonstrat faptul că VTM prezintă valori medii semnificativ mai scăzute la pacienții diagnosticați cu pneumonie față de lotul martor de subiecți sănătoși, fără a analiza însă diferențele de valori în funcție de severitatea manifestărilor respiratorii (25). Similar, am obținut valori medii mai reduse ale VTM în studiul nostru, în sublotul de pneumonii complicate cu insuficiență respiratorie acută față de lotul martor.

În ceea ce privește raportul trombocite/limfocite, Jong Han Lee și colab. au concluzionat într-un studiu retrospectiv că acest parametru poate fi utilizat ca marker inflamator predictiv al severității pneumoniei, întrucât cele mai mari valori ale acestui raport, cu semnificație statistică puternică, s-au înregistrat la pacienții care au necesitat spitalizare în serviciul de terapie intensivă (26). Similar acestui studiu, analiza statistică din cadrul studiului nostru a relevat o creștere semnificativă a aceluiași biomarker la pacienți cu pneumonii complicate cu insuficiență respiratorie acută.

Studiul de față nu este lipsit de limitări, principala limitare fiind numărul redus de pacienți incluși, care fac parte dintr-un singur areal geografic. Deși pacienții incluşi în studiu au prezentat variate tipuri de infecții respiratorii, majoritatea pacienților au fost diagnosticați cu pneumonie și bronșiolită, restul afecțiunilor constituind procente nesemnificative pentru a fi analizate individual. Prin urmare, ar fi necesară extinderea cercetării pe un eșantion populațional pediatric mai amplu, din diverse zone geografice și cu un număr reprezentativ al diverselor afecțiuni respiratorii care nu au fost investigate suficient în cadrul studiului nostru, pentru a putea obține rezultate relevante din punct de vedere statistic. $\mathrm{Cu}$ toate acestea, studiul nostru reprezintă unul dintre puținele de acest gen efectuate la populația pediatrică și singurul până în prezent care a analizat VTM și raportul trombocite/ limfocite în relație cu severitatea afecțiunilor respiratorii. 


\section{CONCLUZII}

Acest studiu a dovedit utilitatea volumului mediu trombocitar şi a raportului trombocite/limfocite ca markeri predictivi ai severității infecțiilor respiratorii acute, îndeosebi ai pneumoniei şi ai bronşiolitei acute

\section{BIBLIOGRAFIE}

1. Tazinya AA, Halle-Ekane GE, Mbuagbaw LT et al. Risk factors for acute respiratory infections in children under five years attending the Bamenda Regional Hospital in Cameroon. BMC Pulmonary Medicine. 2018;18(1):7.

2. Piteau S. Update in pediatrics. Ontario: Springer International Publishing, 2018.

3. Nitu ME, Eigen H. Respiratory failure. Pediatrics in Review. 2009;30(12):470-8.

4. Russell CD, Parajuli A, Gale HJ, et al. The utility of peripheral blood leucocyte ratios as biomarkers in infectious diseases: A systematic review and meta-analysis. Journal of Infection. 2019;78(5):339-48.

5. Kaushansky K. The molecular mechanisms that control thrombopoiesis. Journal of Clinical Investigation. 2005; 115:3339-47.

6. le Tulzo Y, Pangault C, Gacouin A et al. Early circulating lymphocyte apoptosis in human septic shock is associated with poor outcome. Shock. 2002;18(6):487-94.

7. Wyllie DH, Bowler ICJW, Peto TEA. Relation between lymphopenia and bacteraemia in UK adults with medical emergencies. Journal of Clinical Pathology. 2004;57(9):950-5.

8. Qu R, Ling Y, Zhang Y, Hui Zhi et al. Platelet-to-lymphocyte ratio is associated with prognosis in patients with coronavirus disease-19. Journal of Medical Virology. 2020; jmv.25767.

9. Kartal O, At K. Value of neutrophil to lymphocyte and platelet to lymphocyte ratios in pneumonia. Science Edition Bratisl Med J. 2017;118(9):513-6.

10. Bath PMW, Butterworth RJ. Platelet size: Measurement, physiology and vascular disease. In: Blood Coagulation and Fibrinolysis. Lippincott Williams and Wilkins; 1996. p. 157-61.

11. Kisacik B, Tufan A, Kalyoncu U et al. Mean platelet volume (MPV) as an inflammatory marker in ankylosing spondylitis and rheumatoid arthritis. Joint Bone Spine. 2008;75(3):291-4.

12. Milovanovic $M$, Nilsson $E$, Järemo P. Relationships between platelets and inflammatory markers in rheumatoid arthritis. Clinica Chimica Acta. 2004;343(1-2):237-40.

13. Kapsoritakis AN, Koukourakis MI, Sfiridaki A et al. Mean platelet volume: A useful marker of inflammatory bowel disease activity. The American Journal of Gastroenterology. 2001;96(3):776-81.

14. Ergül AB, Torun YA, Uytun S, Aslaner H, Kısaaslan AP, Şerbetçi MC. Reduction in mean platelet volume in children with acute bronchiolitis. Turk Pediatri Arsivi. 2016;51(1):40-5. complicate cu insuficiență respiratorie acută la copil. Totuși, având în vedere numărul limitat de pacienți înrolați în studiu, este necesară extinderea cercetării pe populații pediatrice mai mari și analiza individuală a celor doi parametri pe o sferă mai variată de afecțiuni respiratorii.

15. Giray D, Hallioglu O. Are there any novel markers in acute rheumatic fever: Neutrophil-to-lymphocyte ratio, platelet-to-lymphocyte ratio, and monocyte-to-lymphocyte ratio. Cardiology in the Young. 2020;

16. Solmaz A, Demir A, Gümüş H, Aksoy M, Solmaz F. Neutrophil/ Lymphocyte Ratios, Platelet/Lymphocyte Ratios, and Mean Platelet Volume Values in Patients with Measles. Cureus. 2020;12(1).

17. Bozlu G. Role of mean platelet volume-to-lymphocyte ratio in the diagnosis of childhood appendicitis. Arch Argent Pediatr. 2019;117(6).

18. Özdemir ZC, Çetin N, Kar YD et al. Hematologic Indices for Predicting Internal Organ Involvement in Henoch-Schönlein Purpura (IgA vasculitis). Journal of Pediatric Hematology/Oncology. 2020; 42(1):e46-9.

19. Baghersalimi A, Koohmanaee S, Darbandi B et al. Platelet Indices Alterations in Children with Type 1 Diabetes Mellitus. Journal of Pediatric Hematology/Oncology. 2019;41(4):e227-32.

20. Lee JS, Kim NY, Na SH et al. Reference values of neutrophillymphocyte ratio, lymphocyte-monocyte ratio, platelet-lymphocyte ratio, and mean platelet volume in healthy adults in South Korea. Medicine. 2018;97(26).

21. Ghazizadeh H, Kathryn Bohn M, Kardagh Polus R et al. Comprehensive hematological reference intervals in a healthy adult male population. Cellular and Molecular Biology. 2020;66(2):99.

22. Gunluoglu G, Yazar EE, Veske NS et al. Mean platelet volume as an inflammation marker in active pulmonary tuberculosis. Multidisciplinary Respiratory Medicine. 2014;9(1):11.

23. Gökçe Ş, Kurugöl Z, Suner A. The role of mean platelet volume in the early detection of acute bronchiolitis: A prospective study. Clinical Respiratory Journal. 2018;12(10):2513-8.

24. Renshaw AA, Drago B, Toraya $\mathrm{N}$ et al. Respiratory syncytial virus infection is strongly correlated with decreased mean platelet volume. International Journal of Infectious Diseases. 2013 Sep;17(9).

25. Karadag-Oncel E, Ozsurekci Y, Kara A et al. The value of mean platelet volume in the determination of community acquired pneumonia in children. Italian journal of pediatrics. 2013;39(1):16.

26. Lee JH, Song S, Yoon SY et al. Neutrophil to lymphocyte ratio and platelet to lymphocyte ratio as diagnostic markers for pneumonia severity. British Journal of Biomedical Science. 2016;73(3):140-2.

Conflict of interest: none declared Financial support: none declared 